\title{
Detection of Microcystin (mcyE) Gene in Recreational Lakes in Miri, Sarawak, Malaysia
}

\author{
ROHASLINDA MOHAMAD, MOHD. RAFATULLAH*, \\ TENGKU NADIAH YUSOF, YI JING SIM, NORLI ISMAIL and JAPARENG LALUNG*
}

\author{
Division of Environmental Technology, School of Industrial Technology, \\ Universiti Sains Malaysia, 11800, Pulau Pinang, Malaysia.
}

http://dx.doi.org/10.12944/CWE.11.3.02

(Received: November 22, 2016; Accepted: December 14, 2016)

\begin{abstract}
Toxic cyanobacteria blooms became a worldwide problems as many countries encounter the presence of the blooms in most of water bodies. As part to develop monitoring of cyanobacterial toxins in Malaysia, samples taken in twelve points in five different lakes in Miri, Sarawak. Polymerase chain reaction (PCR) amplification of cyanobacterial 16S rRNA were carried out to detect the presence of cyanobacteria in the water samples. Cyanobacterial 16S rRNA were detected in all the samples collected. While molecular analysis for detection of cyanobacterial toxin encoding gene were done using specific primers. PCR amplification of cyanobacterial toxin-encoding gene were carried using the combination of forward primer; mcyE-F2 and reverse primer; mcyE-R4 to amplify generic microcystin (mcyE) gene in the samples. Out of twelve samples collected, microcystin (mcyE) producing gene was detected in one of the samples tested. Presence of microcystin encoding gene indicates the risk of cyanobacterial toxins in Miri, Sarawak.
\end{abstract}

Keywords: Toxic cyanobacteria, Cyanobacterial toxins, Cyanobacterial 16S rRNA, PCR amplification, microcystin.

\section{INTRODUCTION}

Cyanobacteria, or also known as blue-green algae are prokaryotes with unique characteristics. Unlike most prokaryotes, cyanobacteria consist of chlorophyll that enables them to obtain their nutrient mainly through photosynthetic action. Photosynthesis of the bacteria is important to provide atmospheric oxygen for other organism usage. Cyanobacteria are also important as a potential resource for renewable energy and natural products ${ }^{1}$. However, excessive growth of cyanobacteria leads to formation of cyanobacteria blooms in the water environment. The blooms cause several problems such as unpleasant odour and taste, and most importantly, toxin production?2.

Capability of producing toxins by cyanobacteria was recorded earliest by
Francis ${ }^{3}$. However, understanding of the toxins structure, its genome code and biochemical pathway were known only after few decades later. Cyanobacterial toxins are encoded in a unique gene cluster, which is not species specific, but rather gene specific. That is, same species of cyanobacteria may or may not encode for the same toxin gene and that the same toxin may be encoded by several different species. The toxins are generally categorized in four major groups based on its toxicology effects, which are hepatotoxic toxin (microcystin and nodularin), neurotoxin (anatoxin-a, anatoxin -a(s), and saxitoxin), cytotoxic toxin (cylindrospermopsin) and dermatotoxin (aplysiatoxins, lyngbyatoxin- $A)^{2,4,5}$.

Previous record showed that all the toxins are harmful to human and animals. In 1996, direct exposure to the cyanobacterial toxin during 
routine hemodialysis treatment had caused 116 patients from Brazil to develop hepatotoxicity and neurotoxicity symptoms and 52 of them died due to the cyanobacteria toxication. The symptom is now can be referred as Caruaru syndrome ${ }^{6}$. Efforts in analysing health risk posed by cyanotoxin had been made several times and in 1999, World Health Organization (WHO) had included cyanobacterial toxins in the drinking water guidelines and recreational water guideline.

Currently, more than 65 countries worldwide including Thailand, Vietnam, Philippine, and Singapore have recorded the detection of toxic cyanobacteria in the water environment, with Malaysia confirming presence of toxic cyanobacteria in $2015^{7}$ and toxin-producing Microcystis was successfully isolated from Ayer Itam reservoir, Penang by Sim Yi Jing ${ }^{8}$.

As such, detecting toxin encoding gene cyanobacteria are crucial to clarify the status of cyanobacteria toxin in Malaysia. Researchers have established many toxic cyanobacteria detection methods. Most commonly used in detecting toxin encoding gene cyanobacteria involved molecular typing method such as conventional polymerase chain reaction (PCR). Using the PCR, presence of cyanobacterial toxin encoding gene in Miri, Sarawak, was investigated. To our best knowledge, this is the first research in detecting toxin gene encoding microcystin was conducted in Borneo Malaysia.

\section{METHODS}

\section{Sampling}

The locations involved a district in Sarawak, called Miri. Samples were collected in twelve points around Miri on June 2015. The lakes were located at Taman Tunku, Taman Awam Miri, Miri City Fan, Taman Bulatan and Taman Hilltop (Figure 1). In general, these lakes were manmade lakes located in residential and recreational areas in Miri, Sarawak. These sampling sites were chosen according to the visibility of the greenish organisms in the water bodies indicate the presence of the cyanobacteria. Accessibility and wind direction also taken into consideration in choosing the samples collection stations.

\section{DNA extraction}

DNA extractions from the environment were performed based on Bacterial DNA Extraction Kits (Vivantis) protocol. In brief, $1 \mathrm{ml}$ of cyanobacterial samples were centrifuged at $6000 \mathrm{rpm}$ for 2 minutes and the supernatant were decanted completely. Then, $100 \mu$ l Buffer R1 were added to the pellet and the cells were resuspended completely. $10 \mu \mathrm{l}$ of lysozyme were added into the cell suspension. The cell suspension were mixed thoroughly before incubated at $37^{\circ} \mathrm{C}$ for 20 minutes. After that, the digested cells were pelleted by centrifugation at $10,000 \mathrm{rpm}$ for 3 minutes and supernatant were decanted completely. The pellet were resuspended in $180 \mu \mathrm{l}$ of Buffer R2 and proteinase K were added. The cells suspension were mixed thoroughly and incubate for $20 \mathrm{~min}$ in a shaking thermomixer. Two volumes of Buffer BG (approximately 400 $\mathrm{\mu l}$ ) were added and mixed by several times until a homogenous solution is obtained. The mixture were incubated for $10 \mathrm{~min}$ at $65^{\circ} \mathrm{C}$ before $200 \mu \mathrm{l}$ of absolute ethanol were added. The mixtures were then transferred into a column microfuge. The column was centrifuged at $10,000 \mathrm{rpm}$ for $1 \mathrm{~min}$. The flow through was discarded and washed using Wash Buffer ${ }^{9}$. The column was centrifuged for one minute at $10,000 \mathrm{rpm}$. The column was further centrifuged at the $10,000 \mathrm{rpm}$ for 1 minute to remove residual ethanol. Finally, the extracted DNA was eluted into using pre-heated elution buffer.

Efficiency of DNA extraction was visualized by running through agarose gel. Extracted DNA was stored at -20 degree until required.

\section{PCR}

Cyanobacterial 16S rRNA were detected using primer pairs CYA106F, and CYA781R (a), CYA781R (b) and the sequences for the primer were shown in Table $1^{10,11,12}$.

PCR amplifications were performed with a Mastercycler $\circledast$ ep (Eppendorf). PCR reaction were carried out in $25 \mu \mathrm{L}$ reaction mixtures containing 12.5 $\mu \mathrm{L}$ of 2X Taq Master Mix (Vivantis Technologies), 0.25 $\mu \mathrm{L}$ of each primers (Integrated DNA Technologies) and $2 \mu \mathrm{l}$ of DNA sample combined with sterile distilled $\mathrm{H}_{2} \mathrm{O}$ to a volume of $25 \mu \mathrm{L}$ of total reaction. PCR protocols to amplify cyanobacterial $16 S$ rRNA 
involved an initial denaturation for $2 \mathrm{~min}$ at $95^{\circ} \mathrm{C}$; followed by 30 cycles, each consisting of $60 \mathrm{~s}$ at $94^{\circ} \mathrm{C}, 60 \mathrm{~s}$ at $60^{\circ} \mathrm{C}$, and $60 \mathrm{~s}$ at $72^{\circ} \mathrm{C}$; and a final extension of $7 \mathrm{~min}$ at $72^{\circ} \mathrm{C}^{10,15}$.

After the amplification, the products was loaded on $1 \%$ agarose gel that was prepared by adding $0.25 \mathrm{~g}$ of agarose (Vivantis Technologies) to $25 \mathrm{~mL}$ of $1 \times$ TAE buffer. $2.5 \mu \mathrm{L}$ of gel stain (TransGen Biotech) added into the hot agar. $2 \mu \mathrm{L}$ of $6 \mathrm{X}$ loading dye (Vivantis Technologies) added into the PCR products. Gels were ran at $70 \mathrm{~V}$ for 40 minutes and viewed using Gel Doc ${ }^{\mathrm{TM}}$ XR+ (Bio-Rad).

Generic microcystin (mcyE) gene amplified using forward primer; mcyE-F2 combined with reverse primer; mcyE-R4 ${ }^{16,17}$. While the detection microcystin (mcyE) gene specific for Microcystis sp. used primer pair mcyE-F2 and mcyE-R8 ${ }^{18}$, microcystin (mcyE) gene specific for Anabena sp. used primer pair mcyE-F2 and mcyE-12R ${ }^{18}$ and gene specific for Planktothrix sp. used primer pair mcyE-F2 and mcyE-plaR3 ${ }^{16}$. The sequences for the primers used in amplification for microcystin gene were shown in Table $2^{18}$.

For mcyE gene-generic primers, PCR protocols was performed as followed: The first step was an initial denaturation step of $2 \mathrm{~min}$ at $95^{\circ} \mathrm{C}$ followed by 35 cycles of $30 \mathrm{~s}$ at $94^{\circ} \mathrm{C}, 30 \mathrm{~s}$ at $56^{\circ} \mathrm{C}$ and $60 \mathrm{~s}$ at $72{ }^{\circ} \mathrm{C}$ and a final extension of $10 \mathrm{~min}$ at $72{ }^{\circ} \mathrm{C}^{15,16}$.

PCR protocols for all three mcyE genespecific primers involved of an initial denaturation for $3 \mathrm{~min}$ at $95^{\circ} \mathrm{C}$. For microcystin ( $m c y E$ ) gene specific for Microcystis sp., the initial denaturation step was followed by 25 cycles of $30 \mathrm{~s}$ at $94^{\circ} \mathrm{C}, 30 \mathrm{~s}$ at $60^{\circ} \mathrm{C}$, and $60 \mathrm{~s}$ at $72^{\circ} \mathrm{C}^{18}$. While for microcystin (mcyE) gene specific for Anabena sp., the initial denaturation step was followed by 30 cycles of $30 \mathrm{~s}$ at $94^{\circ} \mathrm{C}, 30 \mathrm{~s}$ at $58^{\circ} \mathrm{C}$, and $60 \mathrm{~s}$ at $72^{\circ} \mathrm{C}^{18}$. For microcystin (mcyE) gene specific for Planktothrix sp., PCR protocols involved of 30 cycles of $30 \mathrm{~s}$ at $94^{\circ} \mathrm{C}, 30 \mathrm{~s}$ at $57^{\circ} \mathrm{C}$, and $60 \mathrm{~s}$ at $72^{\circ} \mathrm{C}^{16}$. All the PCR cycles were followed by a final extension of $10 \mathrm{~min}$ at $72{ }^{\circ} \mathrm{C}^{16,18}$.

\section{DNA purification}

DNA product from the PCR amplification were performed based on Ambiclean Kits (PCR
\& Gel) protocol (Vivantis Technologies) and sent to Center for Chemical Biology for sequencing purposes. The sequence was compared with the available data from National Centre for Biotechnology Information (NCBI) using Blast.

\section{RESULTS}

\section{Detection of cyanobacterial 16S rDNA}

Cyanobacterial 16S rDNA were amplified using primer CYA106F combined with CYA781R (a) and CYA781R (b) to generate a DNA fragment of $654-699$ bp as shown in Figure 2.

All samples shown apparent bands on the gel electrophoresis image indicate the presence of cyanobacterial 16S rRNA (Table 3), showing the presence of the cyanobacteria in the samples.

All samples were tested positive $16 \mathrm{~S}$ rRNA cyanobacterial gene indicates the presence of cyanobacteria in the samples.

\section{Detection of generic microcystin ( $m c y E$ ) gene}

Generic microcystin (mcyE) gene were amplified using primer mcyE-F2 combined with mcyE-R4 to generate a DNA fragment of 809-812 bp as shown in Figure 3.

Only Miri City Fan 1, (Lane 7) was positive for the presence of microcystin gene (Table 4), while other samples shown no bands in gel electrophoresis image.

Microcystin (mcyE) gene was detected in the samples taken from Miri City Fan Lake while others samples shown negative results indicated that the absence of the microcystin gene.

\section{Detection of microcystin ( $m c y E$ ) gene specific for Microcystis sp., Anabaena sp. and Planktothrix} sp.

Microcystin (mcyE) gene specific for Microcystis sp., Anabaena sp. and Planktothrix sp. were amplified using forward primer of mcyE-F2 combined with mcyE-R8 (Microcystis sp.), mcyE12R (Anabaena sp.) and mcyE-plaR3 (Planktothrix sp.) to generate a DNA fragment of $247 \mathrm{bp}$ as shown in Figure 4, Figure 5, and Figure 6 respectively ${ }^{19,20}$. 
PCR amplification for microcystin gene specific to Microcystin sp., Anabaena sp. and Planktothrix sp. shown no bands in gel electrophoresis images (Table 5), showing that microcystin gene was not amplified using the microcystin gene specific primers ${ }^{21}$.

Further PCR amplification were carried out to determine the genera producing the microcystin gene. However, detection of microcystin (mcyE) gene specific for Microcystis sp., Anabaena sp. and Planktothrix sp. showed negative results.

Following the negative results of the detection of microcystin (mcyE) gene specific for genera, the PCR products were cleaned and sent for sequencing to determine the genera producing microcystin gene. The sequence were compared with the available data from in National Centre for Biotechnology Information (NCBI) using BLAST.

Table 1: Sequence of the primers used to amplify cyanobacterial 16S rRNA

\begin{tabular}{ll}
\hline Primers & Sequences (5' to 3') \\
\hline CYA106F & CGG ACG GGT GAG TAA CGC GTG A \\
CYA781R (a) & GAC TAC TGG GGT ATC TAA TCC CTT T \\
CYA781R (b) & GAC TAC AGG GGT ATC TCC CTT T TAA \\
\hline
\end{tabular}

${ }^{*}$ CYA781R primer is used as an equimolar mixture of CYA781R(a) and CYA718R(b).

* Two reverse primers were used as the both primers; CYA781R(a) and CYA718R(b) targets for morphologically different strains as the former targets filamentous cyanobacteria and the latter targets unicellular cyanobacteria ${ }^{13,14}$

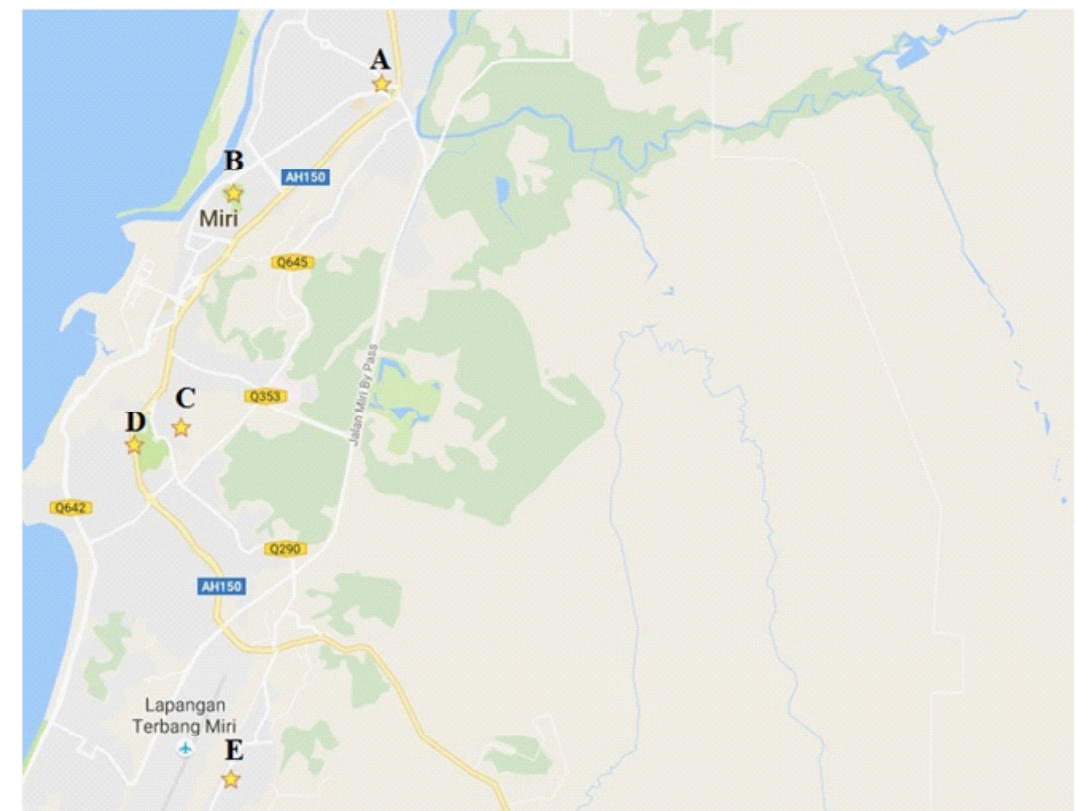

Fig. 1: Map of sampling points in Miri, Sarawak. A) Taman Bulatan Lake, B) Miri City Fan Lake, C) Taman Hiltop Lake, D) Taman Awam Miri Lake, and E) Taman Tunku Lake. 
From the result of comparing the sequence with the available data in NCBI, the highest similarities of the sequence showed was the Microcystis aeruginosa (mcyE) gene 5'-CCCGCCCCTTCCAGCTCGAATA CCCCGCCGCTTCATGCGGTGATCAATGAAAAC ACCTTTTTCGCTTAAAACTGGCGACACAAGAC GCTATCGGTACCGGTATGGTAGAATTTAAGGAA CGAAAAGCTAATCAAGTAAAAGATAATGAACTT

Table 2: Sequence of the primers used to amplify mcyE gene

\section{Primers Sequences (5' to 3')}

\section{mcyE-F2}

mcyE-R4

GAA ATT TGT GTA GAA GGT GC

mcyE-R8 AAT TCT AAA GCC CAA AGA CG

mcyE-12R CAA TGG GAG CAT AAC GAG mcyE-plaR3

* Primer mcyE-F2 was used as forward primer for amplification of both generic and specific microcystin gene.

TGACCCGACCCTGTACATTTTGTATATCATTTGAC TCGCGCAGCTCCTTTTAAACGAGCCATTGTTATTT CCTGTCTTGACGCTAATCACACCAAATGATTTGC ATACTGTTCACCTGCCATATATCCACGATCAGCTG AAATTCTTTTTTTTTTGTAAGTTATGGACACTTTA AAGGATTCTAGGACCTTTATTCTGCTAATTAATTC CCCTTAAGACAACATATATAAAGTGACCTGAACT CACCGACGCGTCAATTATCAACGTGGCACCAATT TGGTTATTCCTCAAAGATTGATCTTTAGAACATAG CTTGGCTTTCTGTGACAAAATTGCGAAGGAAGCT TCCG-3) resulted $66 \%$ identical to the available sequence in the GeneBank.

\section{DISCUSSION}

Both cyanobacterial 16S rRNA and microcystin genes were present throughout the study. Cyanobacterial 16S rRNA gene were detected in all samples collected in lakes located in Miri, Sarawak but microcystin ( $m c y E$ ) gene were detected only in one out of twelve different field samples. In 2012, Harith and Hassan 22 reported the presence of cyanobacteria in Ranchan Pool, Serian, Sarawak. 17 of cyanobacteria species was recorded from the

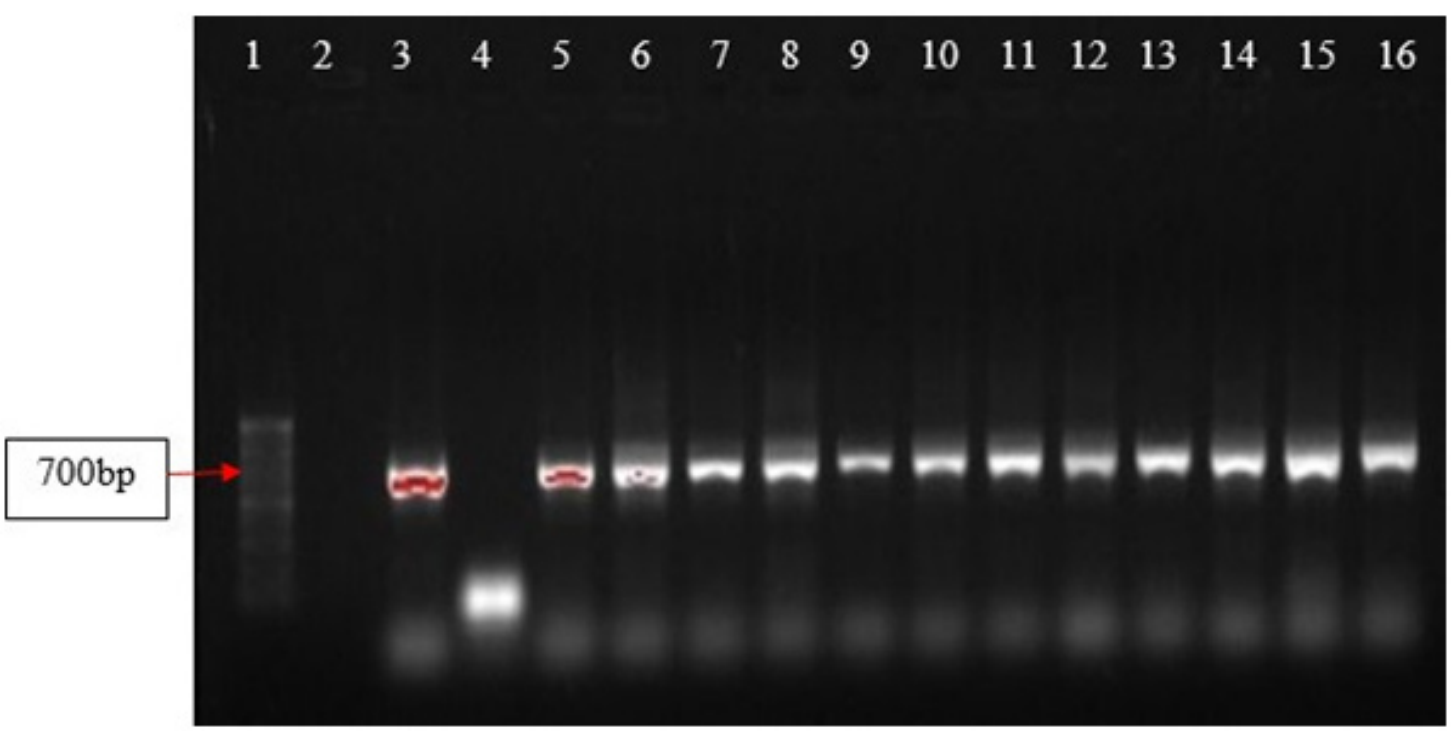

Fig. 2: Agarose gel electrophoresis image of 654-699 bp of PCR product obtained from the use of 16S rRNA primer, CYA 106F as a forward primer combined with two reverse primer; CYA 781R

(a) and CYA 781R (b) on DNA extracts using GF-1 Bacterial DNA Extraction Kit (Vivantis) from samples taken at different lakes in Miri, Sarawak in June 2015. DNA was visible for all samples taken from the lakes. 1 = Ladder (VC 100bp); 2 = Empty; 3 = Positive control; 4 = Negative control; 5 = Taman Tunku; 6 = Taman Awam Miri 1; 7 = Taman Awam Miri 2; 8 = Miri City Fan 1; 9 = Miri City Fan 2; 10 = Miri City Fan 3; 11 = Taman Bulatan 1; 12 = Taman Bulatan 2; 13 = Taman Hilltop 1; 14 = Taman Hilltop 2; 15 = Taman Hilltop 3; 16 = Taman Hilltop 4. 
Table 3: PCR summary results for the presence of cyanobacterial 16S rRNA for the samples taken at different locations in Miri, Sarawak in June 2015. '+' indicate the positive results while "-'indicate the negative results

\begin{tabular}{lc}
\hline Samples & Results \\
\hline Taman Tunku & + \\
Taman Awam Miri 1 & + \\
Taman Awam Miri 2 & + \\
Miri City Fan 1 & + \\
Miri City Fan 2 & + \\
Miri City Fan 3 & + \\
Taman Bulatan 1 & + \\
Taman Bulatan 2 & + \\
Taman Hilltop 1 & + \\
Taman Hilltop 2 & + \\
Taman Hilltop 3 & + \\
Taman Hilltop 4 & + \\
\hline
\end{tabular}

pool including six genera of potential toxin producing genera; Cylindrospermopsis, Nostoc, Lyngbya, Oscillatoria, Scytonema and Synechococcus. Nevertheless, there were no reports of the presence of cyanobacterial toxin from the pool. Studies on cyanobacterial toxins are still limited in Malaysia despite of its harmfulness. This research is the first and important preliminary steps in detection of cyanobacterial toxin in recreational water in Sarawak.

Sampling in tropical countries can be conducted anytime in a year as cyanobacteria blooms possibly occurring all year round ${ }^{23}$. However, it is important to take weather such as temperature and wind into consideration as well, for concentration of cyanobacteria changes within hour depended on wind. Difference concentration of cyanobacteria in sampling may provide inaccurate data on potential toxicities of cyanobacteria to the occasional swimmers and the amount of the toxin potentially entering drinking water ${ }^{2}$. Although cyanobacterial blooms was not visible most of time, but the presence

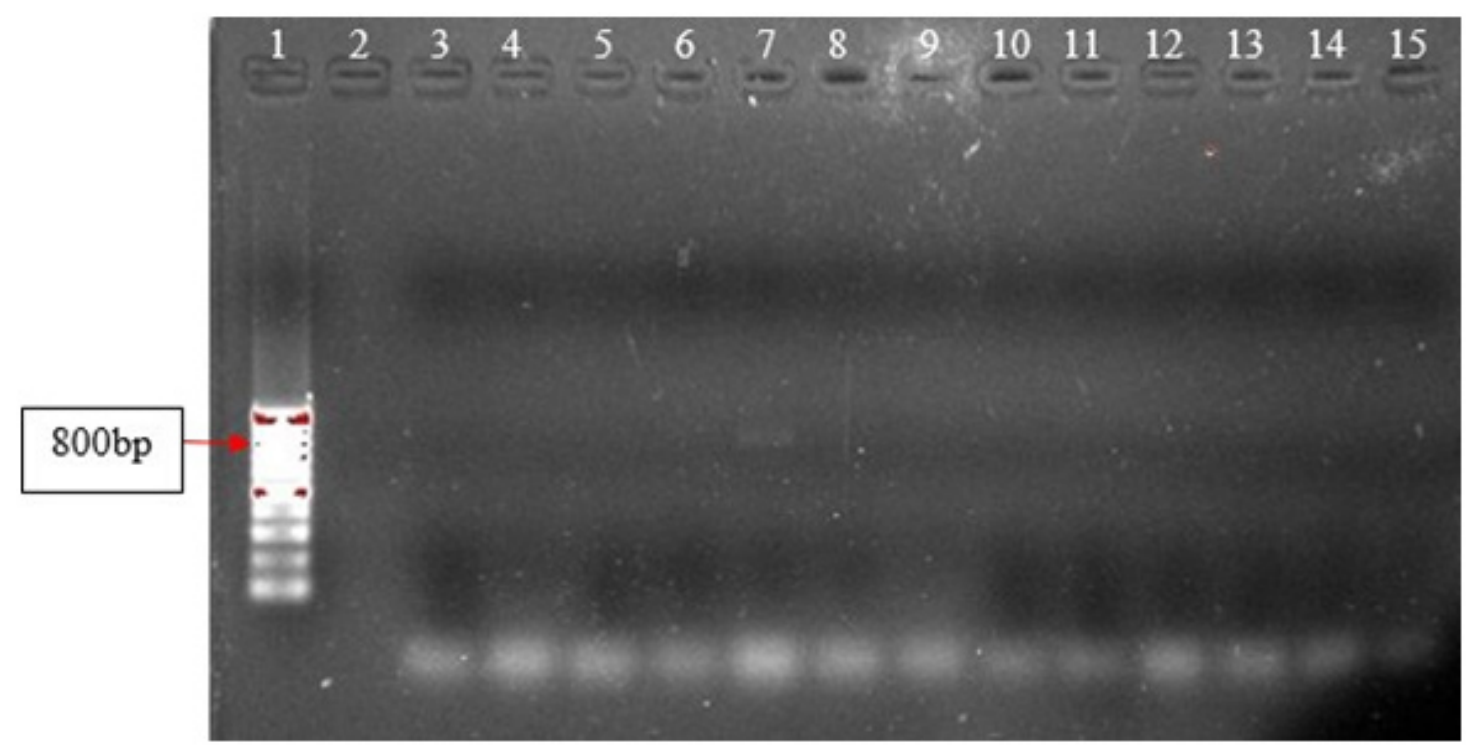

Fig. 3: Agarose gel electrophoresis image of $809-812$ bp of PCR product obtained from the use of generic microcystin (mcyE) gene primers, mcyE-F2 as a forward primer combined with mcyER4 as a reverse primer on DNA extracts using GF-1 Bacterial DNA Extraction Kit (Vivantis) from samples taken at different lakes in Miri, Sarawak in June 2015. DNA was only visible for Miri City Fan 1, (Lane 7) while other samples show negative results. 1 = Ladder (VC 100bp); 2 = Empty; 3 = Negative control; 4 = Taman Tunku; 5 = Taman Awam Miri 1; 6 = Taman Awam Miri 2; 7 = Miri City Fan 1; 8 = Miri City Fan 2; 9 = Miri City Fan 3; 10 = Taman Bulatan 1; 11 = Taman Bulatan 2; 12 = Taman Hilltop 1; 13 = Taman Hilltop 2; 14 = Taman Hilltop 3; 15 = Taman Hilltop 4 
of cyanobacterial toxins should be alerted and monitored because the toxin production is gene specific.

Analytical methods are widely used for detection and quantification of cyanotoxins, but the half-life of the toxins are rather short and easily degraded in the environment. Thus, molecular techniques used to detect genes for toxin production in cyanobacteria in this study because the ability to produce the toxin is gene specific, not species specific. In the environment, microcystin is extremely stable in chemical hydrolysis and extreme high temperature $(>300 æ \% \mathrm{C})^{2}$. Thus may accumulate in the extracellular from several days to years in the environment ${ }^{24}$ after toxic blooming occurrence. However, direct detection of toxins using method such as high performance liquid chromatography

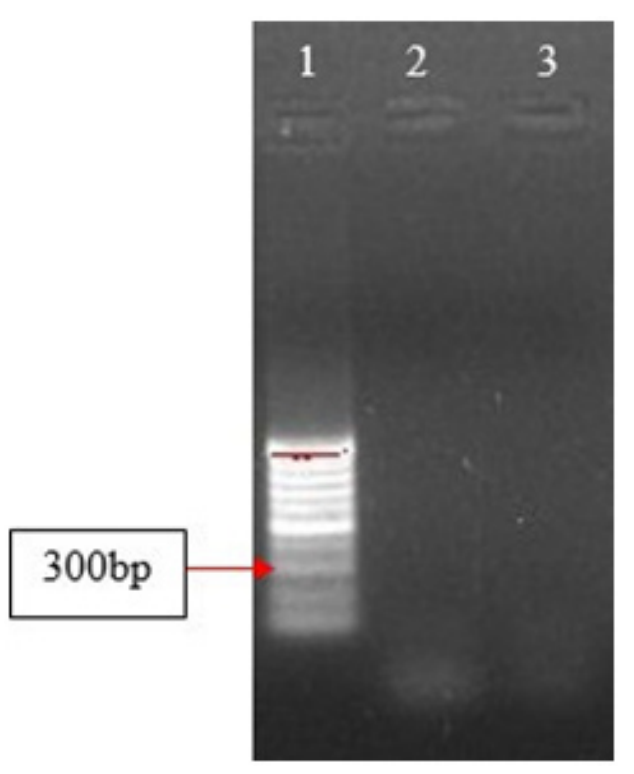

Fig. 4: Agarose gel electrophoresis image of $247 \mathrm{bp}$ of PCR product obtained from the use microcystin (mcyE) gene specific to Microcystis sp. primer, mcyE-F2 as a forward primer combined with mcyE-R8 as a reverse primer on DNA extracts using GF-1 Bacterial DNA Extraction Kit (Vivantis) from samples taken at different lakes in Miri, Sarawak in June 2015. Results were negative except for positive control (Lane 2). 1 = Ladder (VC 100bp); 2 = Positive control; 3 = Negative control; 4 = Miri City Fan 1
(HPLC) is difficult due to its vast different variants. In addition, microcystin is easily degraded by strong oxidation molecules such as ozone and breakdown by the aquatic bacteria ${ }^{2}$ such as Sphingomonas and Pseudomonas aeruginosa ${ }^{24}$ making toxin detection using analytical detection less reliable.

In detecting toxin-producing gene of Microcystis, Anabaena, and Planktothix sp., researchers target $m c y E$ gene from the $m c y S$ gene cluster at the different primer targets ${ }^{25}$. Presences of mcyE gene will immediately confirming the presence of toxic cyanobacteria in an environment ${ }^{26}$ as $m c y E$ gene encode for protein important for the formation of 3-amino-9-methoxy-2,6,8-trimethyl-10-phenyl4,6-decadienoic acid, (Adda) and glutamate-1semialdehyde aminotransferase. Both molecules are important for toxicity ${ }^{27}$. A research showed that

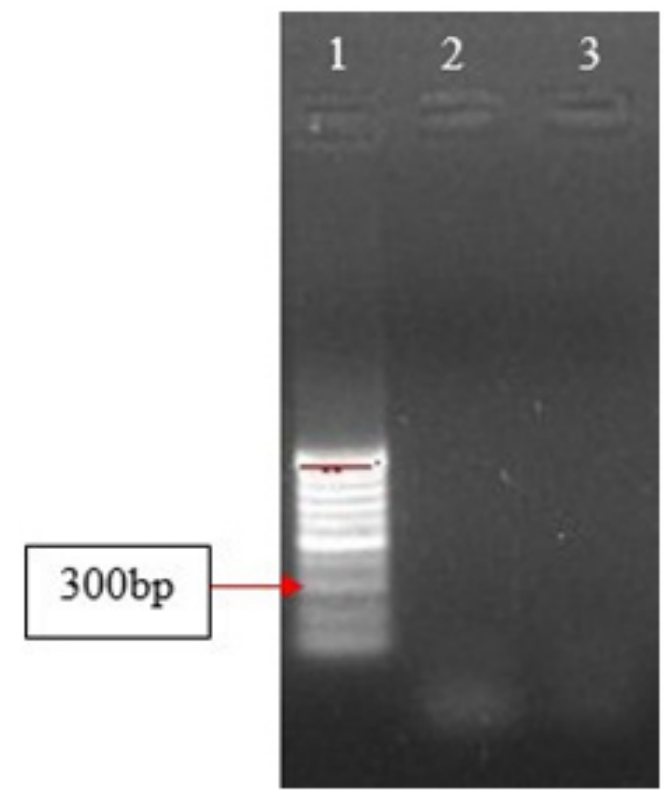

Fig. 5: Agarose gel electrophoresis image of 247 bp of PCR product obtained from the use microcystin (mcyE) gene specific to Anabaena

sp. primer, mcyE-F2 as a forward primer combined with mcyE-12R as a reverse primer on DNA extracts using GF-1 Bacterial DNA Extraction Kit (Vivantis) from samples taken at different lakes in Miri, Sarawak in June 2015. Results were negative for the samples. $1=$ Ladder (VC 100bp); 2 = Negative control; 3 = Miri City Fan 1 
toxicity lost in Planktothrix sp. occurred when up to 90 per cent of $m c y$ gene cluster have lost ${ }^{28}$. However, loss of intergenic region in the gene cluster may have no effect on the expression of the toxin protein ${ }^{29}$. Subsequently, mcy gene detection is used as molecular markers to detect microcystin-producing cyanobacteria in most literature.

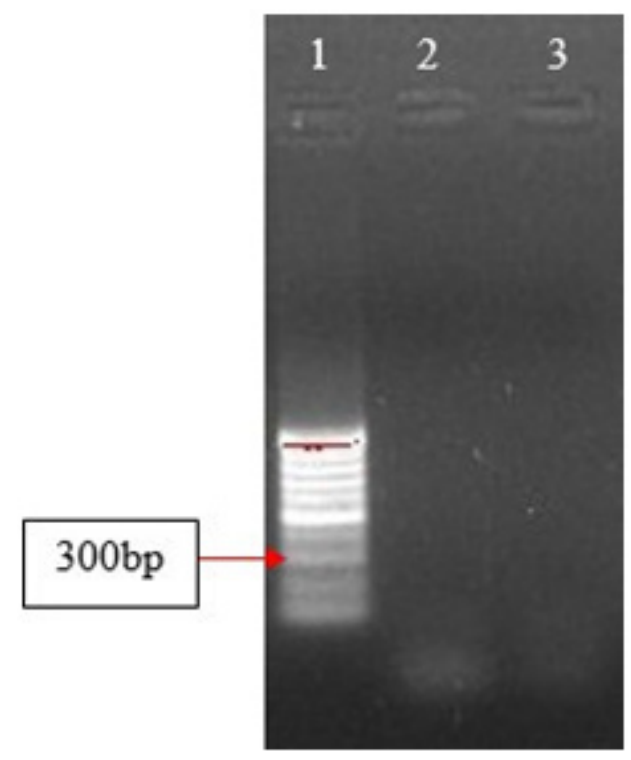

Fig. 6: Agarose gel electrophoresis image of $247 \mathrm{bp}$ of PCR product obtained from the use microcystin gene specific to Planktothrix sp. primer, mcyE-F2 as a forward primer combined with mcyE-12R as a reverse primer on DNA extracts using GF-1 Bacterial DNA Extraction Kit (Vivantis) from samples taken at different lakes in Miri, Sarawak in June 2015. Results were negative for the sample. 1 = Ladder (VC 100bp); 2 = Negative control; 3 = Miri City Fan 1
In conclusion, of twelve samples tested for microcystin encoding gene, only one sample was detected to possess the gene. The result shown the presence of potential risk of cyanobacterial toxin in one of Miri's lake. This study revealed that this is the first time microcystin encoding gene was detected in Borneo Malaysia. The data presented was useful in water risk management and assessment of potential toxin contamination in recreational water in Sarawak.

\section{ACKNOWLEDGMENTS}

The authors are grateful to Universiti Sains Malaysia for providing financial assistance through USM RU grant and MOE ERGS grant

Table 4: PCR summary results for the presence of generic microcystin (mcyE) gene for the samples taken at different locations in Miri, Sarawak in June 2015. ' + ' indicate the positive results while '-' indicate the negative results

\begin{tabular}{lc}
\hline Samples & Results \\
\hline Taman Tunku & - \\
Taman Awam Miri 1 & - \\
Taman Awam Miri 2 & - \\
Miri City Fan 1 & + \\
Miri City Fan 2 & - \\
Miri City Fan 3 & - \\
Taman Bulatan 1 & - \\
Taman Bulatan 2 & - \\
Taman Hilltop 1 & - \\
Taman Hilltop 2 & - \\
Taman Hilltop 3 & - \\
Taman Hilltop 4 & - \\
\hline
\end{tabular}

Table 5: PCR summary results for the presence of specific microcystin (mcyE) gene for the samples of Miri (City Fan) - Planktonic, which shown the positive result for generic microcystins. ' + ' indicate the positive results while '-' indicate the negative results

\begin{tabular}{lccc}
\hline Sample & $\begin{array}{c}\text { Microcystins (mcyE) } \\
\text { gene specific for } \\
\text { Microcystis sp. }\end{array}$ & $\begin{array}{c}\text { Microcystins (mcyE) } \\
\text { gene specific for } \\
\text { Anabaena sp. }\end{array}$ & $\begin{array}{c}\text { Microcystins (mcyE) } \\
\text { gene specific for } \\
\text { Planktothrix sp. }\end{array}$ \\
\hline $\begin{array}{l}\text { Miri City } \\
\text { Fan 1 }\end{array}$ & - & - & - \\
\hline
\end{tabular}


(Grant Number: 1001.PTEKIND.811253 and 203.

PTEKIND.6730135) for this work.

\section{REFERENCES}

1. Beck, C., Knoop, H., Axmann, I. M. and Steuer, R. The diversity of cyanobacterial metabolism: Genome analysis of multiple phototrophic microorganisms. BMC Genomics, 13(56): 1-17 (2012)

2. WHO. Toxic Cyanobacteria in Water: $A$ guide to their public health consequences, monitoring and management. In: INGRID CHORUS \& BARTRAM, J. (eds.). London: E \& FN Spon. (1999)

3. Francis, G. Poisonous Australian lake. Nature, 18: 11-12 (1878)

4. Kaebernick M, and Neilan B. A. Ecological and molecular investigations of cyanotoxin production. FEMS Microbiology Ecology, 35(1): 1-9 (2001)

5. Wood, S. A., Rasmussen, J. P., Holland, P. T., Campbell, R. and Crowe, A. L. M. First report of the cyanotoxin Anatoxin-a from Aphanizomenon issatschenkoi (cyanobacteria). Journal of Phycology, 43(2): 356-365 (2007)

6. Carmichael, W. W., Azevedo, S. M., An, J. S., Molica, R. J., Jochimsen, E. M., Lau, S., Rinehart, K. L., Shaw, G. R. and Eaglesham, G. K. Human fatalities from cyanobacteria: chemical and biological evidence for cyanotoxins. Environmental Health Perspectives, 109(7): 663-668 (2001)

7. Sinang, S. C., Poh, K. B., Shamsudin, S. and Sinden, A. Preliminary Assessment of Cyanobacteria Diversity and Toxic Potential in Ten Freshwater Lakes in Selangor, Malaysia. Bulletin Environmental Contamination of Toxicology, 95(4): 542-547 (2015)

8. Sim, Y.J. Molecular detection of cyanobacterial toxin and control of cyanobacterial population using selected crop wastes. Master of Science, Universiti Sains Malaysia (2015)

9. Suer M. T. An Evaluation of Regulatory T Cell Populations in Orally Tolerized and Antibiotictreated: Ball State University (2010)
10. Nubel, U., Garcia-Pichel, F. and Muyzer, G. PCR primers to amplify $16 S$ rRNA genes from cyanobacteria. Applied and Environmental Microbiology, 63(8): 3327-3332 (1997)

11. Srivastava A., Ara A, Bhargava P., Mishra Y., Rai S., and Rai L. A rapid and cost-effective method of genomic DNA isolation from cyanobacterial culture, mat and soil suitable for genomic fingerprinting and community analysis. Journal of Applied Phycology, 19(4): 373-382 (2007)

12. Banerjee S., Khatoon H., Shariff M. and Yusoff, F. Immobilized periphytic cyanobacteria for removal of nitrogenous compounds and phosphorus from shrimp farm wastewater. Turkish Journal of Biology, 39(3): 388-395 (2015)

13. Boutte, C., Grubisic, S., Balthasart, P. and Wilmotte, A. Testing of primers for the study of cyanobacterial molecular diversity by DGGE. Journal of Microbiological Methods, 65(3): 542-550 (2006)

14. Hashimoto R., Yoshida T., Kuno S., Nishikawa T. and Sako Y. The first assessment of cyanobacterial and diazotrophic diversities in the Japan Sea. Fisheries Science, 78(6): 1293-1300 (2012)

15. Kumar A., Grover S. and Batish V. K. Exploring specific primers targeted against different genes for a multiplex PCR for detection of Listeria monocytogenes. 3 Biotech, 5(3): 261-269 (2015)

16. Rantala, A., Rajaniemi-Wacklin, P., Lyra, C., Lepisto, L., Rintala, J., Mankiewicz-Boczek, J. and Sivonen, K. Detection of microcystinproducing cyanobacteria in Finnish lakes with genus-specific microcystin synthetase gene $\mathrm{E}$ (mcyE) PCR and associations with environmental factors. Applied and Environmental Microbiology, 72(9): 61016110 (2006)

17. Rantala, A., Fewer, D. P., Hisbergues, M., Rouhiainen, L., Vaitomaa, J., Borner, T. and 
Sivonen, K. Phylogenetic evidence for the early evolution of microcystin synthesis. Proceedings of the National Academy Science USA, 101(2): 568-573 (2004)

18. Vaitomaa, J., Rantala, A., Halinen, K., Rouhiainen, L., Tallberg, P., Mokelke, L. and Sivonen, K. Quantitative real-time PCR for determination of microcystin synthetase $\mathrm{e}$ copy numbers for Microcystis and Anabaena in lakes. Applied and Environmental Microbiology, 69(12): 7289-7297 (2003)

19. Vareli K., Touka A., Theurillat X., Briasoulis E., Pilidis G. and Sainis I. Microcystins in Two Low Nutrient Lakes in the Epirus Region of North West Greece. CLEAN-Soil, Air, Water, 43(9): 1307-1315 (2015)

20. Bernardová K., Babica P, Maršálek B, Bláha L. Isolation and endotoxin activities of lipopolysaccharides from cyanobacterial cultures and complex water blooms and comparison with the effects of heterotrophic bacteria and green alga. Journal of Applied Toxicology, 28(1): $72-77$ (2008).

21. Nimptsch J., Woelfl S., Osorio S., Valenzuela J., Moreira C., Ramos V., Castelo Branco R., Leão P. N. and Vasconcelos V. First record of toxins associated with cyanobacterial blooms in oligotrophic North Patagonian lakes of Chile-A genomic approach. International Review of Hydrobiology (2015)

22. Harith, M. N. and Hassan, R. Cyanobacterial Composition of Ranchan Pool, Serian, Sarawak. 4th Regional Conference on Natural Resources in the Tropics, 2012 (NTrop4) (2012)

23. Van Apeldoorn, M. E., Van Egmond, H. P., Speijers, G. J. A. and Bakker, G. J. I. Toxins of cyanobacteria. Molecular Nutrition \& Food Research, 51(1): 7-60 (2007)

24. $\mathrm{Ga}\left(\mathrm{ga}^{3} \mathrm{a}, \mathrm{I}\right.$. and Mankiewicz-Boczek, J. The Natural Degradation of Microcystins (Cyanobacterial Hepatotoxins) in Fresh Water - the Future of Modern Treatment Systems and Water Quality Improvement. Polish Journal of Environmental Studies, 21(5): 1125-1139 (2012)

25. Pearson, L. A. and Neilan, B. A. The molecular genetics of cyanobacterial toxicity as a basis for monitoring water quality and public health risk. Current Opinion in Biotechnology, 19(3): 281-288 (2008)

26. Gkelis, S. and Zaoutsos, N. Cyanotoxin occurrence and potentially toxin producing cyanobacteria in freshwaters of Greece: A multi-disciplinary approach. Toxicon, 78: 1-9 (2014)

27. Glowacka, J., Szefel-Markowska, M., Waleron, M., Lojkowska, E. and Waleron, K. Detection and identification of potentially toxic cyanobacteria in Polish water bodies. Acta Biochima Polonica, 58(3): 321-333 (2011)

28. Sinha, R., Pearson, L. A., Davis, T. W., Muenchhoff, J., Pratama, R., Jex, A., Burford, M. A. and Neilan, B. A. Comparative genomics of Cylindrospermopsis raciborskii strains with differential toxicities. BMC Genomics, 15(1): 83 (2014)

29. Vasas, G., Farkas, O., Borics, G., Felfoldi, T., Sramko, G., Batta, G., Bacsi, I. and Gonda, S. Appearance of Planktothrix rubescens bloom with [D-Asp3, Mdha7]MC-RR in gravel pit pond of a shallow lake-dominated area. Toxins, 5(12): 2434-2455 (2013). 